\title{
EVALUATION OF THE QUALITY OF SLEEP OF THE PROFESSIONAL SOLDIERS POPULATION
}

\author{
Marta Stępień-Słodkowska, ${ }^{1, A, B, D, E}$ Przemysław Ustianowski, ${ }^{1, A, B}$ \\ Anna Starkowska, ${ }^{2, C, D}$ Katarzyna Kotarska ${ }^{1, A, D}$ \\ ${ }^{1}$ Faculty of Physical Education and Health Promotion, University of Szczecin, Poland \\ 2 Department of Psychiatry, Pomeranian Medical University, Szczecin, Poland

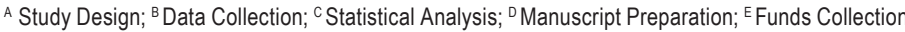 \\ Address for correspondence: \\ Marta Stępień-Słodkowska \\ Faculty of Physical Education and Health Promotion, University of Szczecin \\ Al. Piastów 40B, 71-065 Szczecin, Poland \\ Email: marta.slodkowska1@wp.pl
}

\begin{abstract}
Ahstract The aim of this study was to identify sleep problems in a select group of professional soldiers. For the study used a questionnaire containing the Athens Insomnia Scale by Soldatos, allowing klinimetric evaluation of sleep disorders reflecting mainly insomnia. Material Data were obtained from 200 professional soldiers. The results showed no pathological abnormalities of sleep study population, however, the results show some reduction in the prevalence of symptoms of sleep quality based on the selected factors. The health status of all the soldiers experiencing combat stress requires periodic and thorough control since the diagnosis of disorders is difficult and they can appear even after a long period of lived events. This may lead to look for other ways to deal with problems; the use of psychoactive substances or drug abuse. Therefore it is extremely important to use therapeutic activities.
\end{abstract}

Key WOrlds quality of sleep, Athens insomnia scale, professional soldiers

\section{Introduction}

With the development of civilization, people are subjected to the influence of adverse external factors that may contribute to the reduced quality of life. External stimuli, causing stimulation, stress and other negative emotional states contribute to the pathology of the functioning of the human body. A phenomenon more common among adults is reducing the quality of sleep or sleep disorders, or irregularity occurring during one of the basic physiological needs of the body.

In the literature, the most common is considered the division of sleep disorders given by Bilikiewicz et al. (2002). According to this it may appear insomnia or disorder occurring in the form of insomnia, which may be temporary for the duration of several days, due to a work shift, sudden stressful situations or sudden crossing time zone. Lasting up to three weeks insomia manifested, among others the sudden somatic disease or chronic stress 
associated with other circumstances. While the chronic insomnia is diagnosed when it takes more than one month. This type of disorder is usually accompanied by malaise during the day, sleepiness, fatigue and low mood and motivation, and consequently lower the efficiency of tasks. By definition, the ICD-10 Chronic insomnia is inadequate amount of sleep, which occurs at least three times a week for at least a month. Another disorder is excessive sleepiness also known as hypersomnia. This is increased sleepiness despite the rest of the night, prolongation of sleep or sleepy in a situation requiring activity. While the disorders called parasomnias are undesirable disorder, the most common motor, occurring mainly during wake from sleep, partial awakenings, or in the transition between sleep and wakefulness, or other phases of sleep. Very important in the diagnosis of disorders of has patient declarant problems and also the appropriate tools to diagnose the disorder or other signs of demonstrating the decline in quality of sleep.

One of the goals of the functioning of the army is to conduct training and combat operations during the war. Professional soldiers forms a team undertaking often difficult and dangerous tasks that require possession of specific skills, knowledge and social competencies (Piórowski, 2008). Working in the Army requires from soldiers high responsibility for the health and life of their own and others. Execution of tasks is accompanied by a lot of stressful situations, which, in combination with specific personality traits can cause health effects such as high blood pressure, increased risk of coronary heart disease, increased cholesterol, decreased resistance to infections or develop other psychosomatic diseases (Tomaszewska, 2008; Nowicki et al., 2016). Freeman and Kimbrell (2004) showed that the main health problems in the population of the soldiers involved in the fighting, such as; depression, aggression, psychoactive substance misuse and social isolation are closely associated with posttraumatic stress disorder PTSD. The symptoms of this condition are excessive vigilance and anxiety as well as avoiding memories and recurrent thoughts (Basińska, 2004). Epidemiological studies conducted among American soldiers participating in peacekeeping missions showed that as many as $10 \%$ of them leave the area of combat operations due to mental disorders (Rasmus, 2013). For this reason it is very important to identify any signs of deterioration in the quality of life because of the experience and provide appropriate expert assistance to this population.

The aim of this study was to identify sleep problems in a selected group of professional soldiers.

\section{Material and methods}

The studies used purposeful selection and a select group of former professional soldiers. Permission to carry out tests gave Undersecretary of State in the Ministry of National Defence on the basis of Decision No 78 / MON of the Minister of National Defence of 15 February 2008.

The study material consisted data obtained from 200 soldiers, including 26 women (13\%) and 174 men (87\%). The respondents ranged in age from 22 to 49 years; the average age was $M=32.96$ with a standard deviation SD $=5.82$. The group consisted of 16 officers, 82 NCOs and 102 privates (Table 1). Job experience surveyed ranged from 1 year to 30 years $(M=8.31$; $S D=5.90)$. The sub-group of soldiers who participated in the mission of the war consisted of 73 people, including 4 women (5.5\% of the total study population) and 69 men $(94.5 \%$ of the total study population) aged 23 to 49 years $(M=34,27 ; S D=5.26)$. Professional experience in this subgroup ranged from 1 year to 30 years $(M=11.29, S D=4.73$ ). Most of them (45 people; $61.6 \%$ ) participated in the mission of war 1 time in two missions attended 16 people representing $21.9 \%$ of the respondents, 6 persons (8.2\%) went 3 times, and 3 people (4.1\%) went successively 4 and 5 times. The statistical analysis examined soldiers were divided into 
3 groups: staff who have never participated in a military mission $(n=127)$, the soldiers who went on a mission 1 time $(n=45)$ and the military who participated in the mission 2 and more times $(n=28)$.

Table 1. Characteristics of the study population

\begin{tabular}{lrlr}
\hline \multicolumn{1}{c}{ Gender } & N & \multicolumn{1}{c}{ Corps soldier } & $n$ \\
\hline Woman & 26 & Oficers & 16 \\
Man & 174 & NCOs & 82 \\
& & Privates & 102 \\
\hline
\end{tabular}

Data from respondents was obtained by diagnostic survey, the survey technique (Babie, 2009). Used tool; questionnaire containing the Athens Insomnia Scale by Soldatos (2000) allows klinimetric evaluation of sleep disorders reflecting mainly insomnia. It consists of 8 questions for which the respondent marked the one of the 4 possible answers. Each of the answers are assigned points (from 0 to 3 ) and the sum of their shows on the severity of the symptoms of sleep disorders. Obtaining 5 points or less indicates normal course of sleep stages, from 6 to 10 points is on the border of norms and should pay attention to the basic rules of sleep hygiene and further observation and eventual therapy, while above 10 points indicates insomnia and the necessity of detailed diagnostics and the appropriate therapy strategy (Fornal-Pawłowska et al., 2011).

\section{Results}

The results showed a good or average quality of sleep in the studied group of professional soldiers (Table 2). However, in this population they were also people of low quality requiring a detailed diagnosis and therapy.

Table 2. Distribution of the results of measuring the quality of sleep in a group of professional soldiers

\begin{tabular}{lccc}
\cline { 2 - 3 } & \multicolumn{3}{c}{ Quality of sleep } \\
\cline { 2 - 4 } & Good (0-5 points) & Average (6-10 points) & Low (less then 10 points) \\
\hline Soldiers not participating in missions & $52(71.2 \%)$ & $17(23.3 \%)$ & $4(5.5 \%)$ \\
Soldiers participating in missions & $97(77.0 \%)$ & $25(19.8 \%)$ & $4(3.2 \%)$ \\
\hline All & $149(74.9 \%)$ & $42(21.1 \%)$ & $8(4.0 \%)$ \\
\hline
\end{tabular}

In relation to the number of completed peacekeeping missions and stabilization operations, among examined soldiers observed one being statistically significant difference [X2 ( $\mathrm{df}=4)=13.362 ; p<0.01]$, which concerned the indicator sleep continuity (Table 3). The analysis shows that the problem is the smallest among soldiers who have decided to participate in peacekeeping or stabilization operation several times - as many as half of them sleeps overnight in a continuous manner, and $36 \%$ wakes up occasionally. In the subgroup of stationary soldiers prevailed occasional awakening while frequent interruptions in sleep were most common in the military, who went on a mission once and decided not to do it again. Over $22 \%$ of them are experiencing frequent awakenings during the night. 
Table 3. Symptoms of sleep disorders among soldiers, depending on the number of completed military missions

\begin{tabular}{|c|c|c|c|c|c|c|}
\hline & \multirow{2}{*}{\multicolumn{3}{|c|}{ Number of military missions }} & & & \\
\hline & & & & \multicolumn{3}{|c|}{ Test chi-square } \\
\hline & $\begin{array}{c}0 \\
n=127\end{array}$ & $\begin{array}{c}1 \\
n=45\end{array}$ & $\begin{array}{c}2 \text { and more } \\
n=28\end{array}$ & $x^{2}$ & $d f$ & $\mathrm{p}$ \\
\hline \multicolumn{7}{|c|}{ The speed of falling asleep } \\
\hline Fast & $79(62.2 \%)$ & $26(57.8 \%)$ & $16(57.1 \%)$ & & & \\
\hline With a slight delay & $35(27.6 \%)$ & $9(20.0 \%)$ & $9(32.1 \%)$ & 5.079 & 4 & 0.279 \\
\hline With delay & $13(10.2 \%)$ & $10(22.2 \%)$ & $3(10.7 \%)$ & & & \\
\hline \multicolumn{7}{|c|}{ Awakening in the night } \\
\hline None & $42(33.1 \%)$ & $13(28.9 \%)$ & $14(50.0 \%)$ & & & \\
\hline Sporadic & $77(60.6 \%)$ & $22(48.9 \%)$ & $10(35.7 \%)$ & 13.362 & 4 & 0.009 \\
\hline Frequent & $8(6.3 \%)$ & $10(22.2 \%)$ & $4(14.3 \%)$ & & & \\
\hline \multicolumn{7}{|c|}{ Awakening the in the morning } \\
\hline None & $84(66.1 \%)$ & $22(48.9 \%)$ & $19(67.9 \%)$ & & & \\
\hline Little earlier & $38(29.9 \%)$ & $20(44.4 \%)$ & $8(28.6 \%)$ & 4.662 & 4 & 0.324 \\
\hline Much earlier & $5(3.9 \%)$ & $3(6.7 \%)$ & $1(3.6 \%)$ & & & \\
\hline \multicolumn{7}{|c|}{ Total sleep time } \\
\hline Sufficient & $78(61.4 \%)$ & $23(51.1 \%)$ & $16(57.1 \%)$ & & & \\
\hline Slightly insufficient & $40(31.5 \%)$ & $18(40.0 \%)$ & $10(35.7 \%)$ & 1.498 & 4 & 0.827 \\
\hline Clearly insufficient & $9(7.15)$ & $4(8.9 \%)$ & $2(7.1 \%)$ & & & \\
\hline \multicolumn{7}{|c|}{ Quality of sleep } \\
\hline Satisfying & $83(65.4 \%)$ & $26(57.8 \%)$ & $19(67.9 \%)$ & & & \\
\hline Slightly unsatisfying & $40(31.5 \%)$ & $15(33.3 \%)$ & $8(28.6 \%)$ & 2.992 & 4 & 0.559 \\
\hline Clearly unsatisfying & $4(3.1 \%)$ & $4(8.9 \%)$ & $1(3.6 \%)$ & & & \\
\hline \multicolumn{7}{|c|}{ Frame of daily mind } \\
\hline Good & $98(77.2 \%)$ & $33(73.3 \%)$ & $22(78.6 \%)$ & & & \\
\hline Slightly worse & $27(21.3 \%)$ & $10(22.2 \%)$ & $5(17.9 \%)$ & 1.494 & 4 & 0.829 \\
\hline Clearly worse & $2(1.6 \%)$ & $2(4.4 \%)$ & $1(3.6 \%)$ & & & \\
\hline \multicolumn{7}{|c|}{ Psychophysical efficiency by the day } \\
\hline Correct & $105(82.7 \%)$ & $35(77.8 .0 \%)$ & $25(89.3 \%)$ & & & \\
\hline Slightly disturbed & $20(15.7 \%)$ & $9(20.0 \%)$ & $3(10.7 \%)$ & 1.804 & 4 & 0.772 \\
\hline Clearly disturbed & $2(1.6 \%)$ & $1(2.2 \%)$ & $0(0 \%)$ & & & \\
\hline \multicolumn{7}{|c|}{ Sleepiness during the day } \\
\hline None & $52(41.3 \%)$ & $14(31.1 \%)$ & $12(42.9 \%)$ & & & \\
\hline Slight & $64(50.8 \%)$ & $27(60.0 \%)$ & $12(42.9 \%)$ & 3.049 & 4 & 0.550 \\
\hline Significant & $10(7.9 \%)$ & $4(8.9 \%)$ & $4(14.3 \%)$ & & & \\
\hline
\end{tabular}

The degree of military showed differences in the examined soldiers under the terms of two of the eight indicators of sleep problems. In both cases, the results of the analysis seem to indicate greater severity of the problem in a group of non-commissioned officers (Table 4). Compared with other groups, often they face the problem of interrupted sleep, which complains of more than $18 \%$ of non-commissioned officers. In addition, $12 \%$ of them estimated the total time of their sleep as definitely insufficient. However, the results suggest that these ailments are the smallest among the officers. Half of them sleeps all night in a continuous manner, and nearly $63 \%$ believed that the time spent on sleep during the day for them is entirely satisfactory. Satisfying sleep time was characterized by the almost $68 \%$ privates. 
Table 4. Symptoms of sleep disorders of soldiers, depending on the military rank

\begin{tabular}{|c|c|c|c|c|c|c|}
\hline & \multirow{2}{*}{\multicolumn{3}{|c|}{ Military rank }} & & & \\
\hline & & & & \multicolumn{3}{|c|}{ Test chi-square } \\
\hline & \multirow{2}{*}{$\begin{array}{l}\text { Oficer } \\
n=16\end{array}$} & \multirow{2}{*}{$\begin{array}{l}\text { NCOs } \\
n=82\end{array}$} & \multirow{2}{*}{$\begin{array}{l}\text { Private } \\
n=102\end{array}$} & \multirow{2}{*}{$x^{2}$} & \multirow{2}{*}{$d f$} & \multirow{2}{*}{$p$} \\
\hline & & & & & & \\
\hline \multicolumn{7}{|c|}{ The speed of falling asleep } \\
\hline Fast & $10(62.5 \%)$ & $47(57.3 \%)$ & $64(62.7 \%)$ & & & \\
\hline With a slight delay & $3(18.8 \%)$ & $19(23.2 \%)$ & $31(30.4 \%)$ & 7.559 & 4 & 0.109 \\
\hline With delay & $3(18.8 \%)$ & $16(19.5 \%)$ & $7(6.9 \%)$ & & & \\
\hline \multicolumn{7}{|c|}{ Awakening in the night } \\
\hline None & $8(50.0 \%)$ & $28(34.1 \%)$ & $33(32.4 \%)$ & & & \\
\hline Sporadic & $7(43.8 \%)$ & $39(47.6 \%)$ & $63(61.8 \%)$ & 10.026 & 4 & 0.040 \\
\hline Frequent & $1(6.2 \%)$ & $15(18.3 \%)$ & $6(5.9 \%)$ & & & \\
\hline \multicolumn{7}{|c|}{ Awakening the in the morning } \\
\hline None & $11(68.8 \%)$ & $43(52.4 \%)$ & $71(69.6 \%)$ & & & \\
\hline Little earlier & $4(25.0 \%)$ & $34(41.5 \%)$ & $28(27.5 \%)$ & 6.419 & 4 & 0.170 \\
\hline Much earlier & $1(6.2 \%)$ & $5(6.1 \%)$ & $3(2.9 \%)$ & & & \\
\hline \multicolumn{7}{|c|}{ Total sleep time } \\
\hline Sufficient & $10(62.5 \%)$ & $38(46.3 \%)$ & $69(67.6 \%)$ & & & \\
\hline Slightly insufficient & $5(31.2 \%)$ & $34(41.5 \%)$ & $29(28.4 \%)$ & 10.069 & 4 & 0.039 \\
\hline Clearly insufficient & $1(6.2 \%)$ & $10(12.2 \%)$ & $4(3.9 \%)$ & & & \\
\hline \multicolumn{7}{|c|}{ Quality of sleep } \\
\hline Satisfying & $13(81.2 \%)$ & $45(54.9 \%)$ & $70(68.6 \%)$ & & & \\
\hline Slightly unsatisfying & $3(18.8 \%)$ & $32(39.0 \%)$ & $28(27.5 \%)$ & 6.243 & 4 & 0.182 \\
\hline Clearly unsatisfying & $0(0 \%)$ & $5(6.1 \%)$ & $4(3.9 \%)$ & & & \\
\hline \multicolumn{7}{|c|}{ Frame of daily mind } \\
\hline Good & $15(93.8 \%)$ & $60(73.2 \%)$ & $78(76.5 \%)$ & & & \\
\hline Slightly worse & $1(6.2 \%)$ & $18(22.0 \%)$ & $23(22.5 \%)$ & 5.748 & 4 & 0.219 \\
\hline Clearly worse & $0(0 \%)$ & $4(4.9 \%)$ & $1(1.0 \%)$ & & & \\
\hline \multicolumn{7}{|c|}{ Psychophysical efficiency by the day } \\
\hline Correct & $13(81.2 \%)$ & $69(84.1 \%)$ & $83(81.4 \%)$ & & & \\
\hline Slightly disturbed & $3(18.8 \%)$ & $11(13.4 \%)$ & $18(17.6 \%)$ & 1.542 & 4 & 0.819 \\
\hline Clearly disturbed & $0(0 \%)$ & $2(2.4 \%)$ & $1(1.0 \%)$ & & & \\
\hline \multicolumn{7}{|c|}{ Sleepiness during the day } \\
\hline None & $7(43.8 \%)$ & $28(34.1 \%)$ & $43(42.6 \%)$ & & & \\
\hline Slight & $8(50.0 \%)$ & $44(53.7 \%)$ & $51(50.5 \%)$ & 2.547 & 4 & 0.636 \\
\hline Significant & $1(6.2 \%)$ & $10(12.2 \%)$ & $7(6.9 \%)$ & & & \\
\hline
\end{tabular}

Experience of direct participation in the fighting and exchanging fire with the enemy during the event of military missions was associated with total sleep time per day (Table 5). All the soldiers who have not experienced such an event, judged as sufficient sleep time, or slightly less than satisfactory. In contrast, every tenth military, who survived contact with the enemy fire rated total time of his dream as very insufficient. 
Table 5. Symptoms of sleep disorders among soldiers who participated in direct combat while military mission

\begin{tabular}{|c|c|c|c|c|c|}
\hline & \multirow{2}{*}{\multicolumn{2}{|c|}{ Participation in the fighting }} & \multirow{2}{*}{\multicolumn{3}{|c|}{ Test chi-square }} \\
\hline & & & & & \\
\hline & $\begin{array}{c}\text { YES } \\
n=56\end{array}$ & $\begin{array}{c}\text { NO } \\
n=17\end{array}$ & $x^{2}$ & $d f$ & $p$ \\
\hline \multicolumn{6}{|c|}{ The speed of falling asleep } \\
\hline Fast & $32(57.1 \%)$ & $10(58.8 \%)$ & & & \\
\hline With a slight delay & $15(26.8 \%)$ & $3(17.6 \%)$ & 0.855 & 2 & 0.652 \\
\hline With delay & $9(16.1 \%)$ & $4(23.5 \%)$ & & & \\
\hline \multicolumn{6}{|c|}{ Awakening in the night } \\
\hline None & $20(35.7 \%)$ & $7(41.2 \%)$ & & & \\
\hline Sporadic & $26(46.4 \%)$ & $6(35.3 \%)$ & 0.693 & 2 & 0.707 \\
\hline Frequent & $10(17.9 \%)$ & $4(23.5 \%)$ & & & \\
\hline \multicolumn{6}{|c|}{ Awakening the in the morning } \\
\hline None & $32(57.1 \%)$ & $9(52.9 \%)$ & & & \\
\hline Little earlier & $20(35.7 \%)$ & $8(47.1 \%)$ & 1.693 & 2 & 0.429 \\
\hline Much earlier & $4(7.1 \%)$ & $0(0 \%)$ & & & \\
\hline \multicolumn{6}{|c|}{ Total sleep time } \\
\hline Sufficient & $33(58.9 \%)$ & $6(35.3 \%)$ & & & \\
\hline Slightly insufficient & $17(30.4 \%)$ & $11(64.7 \%)$ & 7.196 & 2 & 0.027 \\
\hline Clearly insufficient & $6(10.7 \%)$ & $0(0 \%)$ & & & \\
\hline \multicolumn{6}{|c|}{ Quality of sleep } \\
\hline Satisfying & $36(64.3 \%)$ & $9(52.9 \%)$ & & & \\
\hline Slightly unsatisfying & $16(28.6 \%)$ & $7(41.2 \%)$ & 0.960 & 2 & 0.619 \\
\hline Clearly unsatisfying & $4(7.1 \%)$ & $1(5.9 \%)$ & & & \\
\hline \multicolumn{6}{|c|}{ Frame of daily mind } \\
\hline Good & $43(76.8 \%)$ & $12(70.6 \%)$ & & & \\
\hline Slightly worse & $11(19.6 \%)$ & $4(23.5 \%)$ & 0.332 & 2 & 0.847 \\
\hline Clearly worse & $2(3.65)$ & $1(5.9 \%)$ & & & \\
\hline \multicolumn{6}{|c|}{ Psychophysical efficiency by the day } \\
\hline Correct & $47(83.9 \%)$ & $13(76.5 \%)$ & & & \\
\hline Slightly disturbed & $8(14.3 \%)$ & $4(23.5 \%)$ & 1.070 & 2 & 0.586 \\
\hline Clearly disturbed & $1(1.8 \%)$ & $0(0 \%)$ & & & \\
\hline \multicolumn{6}{|c|}{ Sleepiness during the day } \\
\hline None & $21(37.5 \%)$ & $5(29.4 \%)$ & & & \\
\hline Slight & $28(50 \%)$ & $11(64.7 \%)$ & 1.289 & 2 & 0.525 \\
\hline Significant & $7(12.5 \%)$ & $1(5.9 \%)$ & & & \\
\hline
\end{tabular}

Like in the case of direct participation in the fighting, the fact of physical injury during military mission was associated with shorter total sleep time (Table 6). Slightly more than $13 \%$ of soldiers who have been injured or involved in the incident in which someone was injured or killed, rated sleep duration as clearly insufficient, while the problem has not occurred at all among respondents who participated in the mission, but not suffered physical damage. 
Table 6. Symptoms of sleep disorders among soldiers during a military mission were injured or involved in the incident in which someone was injured or killed

\begin{tabular}{|c|c|c|c|c|c|}
\hline & \multirow{2}{*}{\multicolumn{2}{|c|}{ Physical injuries }} & \multirow{2}{*}{\multicolumn{3}{|c|}{ Test chi-square }} \\
\hline & & & & & \\
\hline & YES & NO & \multirow{2}{*}{$x^{2}$} & \multirow{2}{*}{ df } & \multirow{2}{*}{$\mathrm{p}$} \\
\hline & $\mathrm{n}=45$ & $n=29$ & & & \\
\hline \multicolumn{6}{|c|}{ The speed of falling asleep } \\
\hline Fast & $24(53.3 \%)$ & $19(65.6 \%)$ & & & \\
\hline With a slight delay & $14(31.1 \%)$ & $4(13.8 \%)$ & 2.889 & 2 & 0.236 \\
\hline With delay & $7(15.6 \%)$ & $6(20.7 \%)$ & & & \\
\hline \multicolumn{6}{|c|}{ Awakening in the night } \\
\hline None & $14(31.1 \%)$ & $14(48.3 \%)$ & & & \\
\hline Sporadic & $23(51.1 \%)$ & $9(31.0 \%)$ & 3.096 & 2 & 0.213 \\
\hline Frequent & $8(17.8 \%)$ & $6(20.7)$ & & & \\
\hline \multicolumn{6}{|c|}{ Awakening the in the morning } \\
\hline None & $25(55.6 \%)$ & $17(58.6 \%)$ & & & \\
\hline Little earlier & $17(37.8 \%)$ & $11(37.9 \%)$ & 0.367 & 2 & 0.832 \\
\hline Much earlier & $3(6.7 \%)$ & $1(3.4 \%)$ & & & \\
\hline \multicolumn{6}{|c|}{ Total sleep time } \\
\hline Sufficient & $27(60.0 \%)$ & $13(44.8 \%)$ & & & \\
\hline Slightly insufficient & $12(26.7 \%)$ & $16(55.2 \%)$ & 8.405 & 2 & 0.015 \\
\hline Clearly insufficient & $6(13.3 . \%)$ & $0(0 \%)$ & & & \\
\hline \multicolumn{6}{|c|}{ Quality of sleep } \\
\hline Satisfying & $27(60 \%)$ & $19(65.5 \%)$ & & & \\
\hline Slightly unsatisfying & $14(31.1 \%)$ & $9(31 \%)$ & 0.859 & 2 & 0.651 \\
\hline Clearly unsatisfying & $4(8.9 \%)$ & $1(3.4 \%)$ & & & \\
\hline \multicolumn{6}{|c|}{ Frame of daily mind } \\
\hline Good & $35(77.8 \%)$ & $21(72.4 \%)$ & & & \\
\hline Slightly worse & $9(20 \%)$ & $6(20.7 \%)$ & 1.022 & 2 & 0.600 \\
\hline Clearly worse & $1(2.2 \%)$ & $2(6.9 \%)$ & & & \\
\hline \multicolumn{6}{|c|}{ Psychophysical efficiency by the day } \\
\hline Correct & $37(82.2 \%)$ & $24(82.8 \%)$ & & & \\
\hline Slightly disturbed & $7(15.6 \%)$ & $5(17.2 \%)$ & 0.676 & 2 & 0.713 \\
\hline Clearly disturbed & $1(2.2 \%)$ & $0(0 \%)$ & & & \\
\hline \multicolumn{6}{|c|}{ Sleepiness during the day } \\
\hline None & $16(35.6 \%)$ & $10(34.5 \%)$ & & & \\
\hline Slight & $23(51.1 \%)$ & $17(58.6 \%)$ & 0.866 & 2 & 0.649 \\
\hline Significant & $6(13.3 \%)$ & $2(6.9 \%)$ & & & \\
\hline
\end{tabular}

\section{Discussion}

The study group of soldiers was characterized by good or slightly reduced quality of sleep. The results of statistical analysis showed a reduced quality of sleep in a group of non-commissioned officers. However, the results suggest that these problems are the slightest among the officers. The results are consistent with studies available in the literature (Chou et al., 2016), in which the officers were characterized by the lowest intensity of sleep problems than the remaining military personnel. This may be due to greater resistance, better professional 
preparation, experience as well as specific personal qualities of officers that meet the protective function, making them more resistant against mentally difficult and stressful situations. An example of such factor may be a sense of coherence, a type of resource resistance unit when it has a conviction that stimulus coming from the external and internal environment are consistent, clear and explicable and access to appropriate resources allows you to cope with them. This feature has been determined by the author of the theory Antonovskiego "resourcefulness". Sense of coherence, as research has shown, reduces the risk of mental disorders caused by job stress (Basińska, 2007). Another feature affecting the functioning of the human being is emotional intelligence. It is the ability to correct perception, assessment and expression of emotions. High levels of emotional intelligence may be a factor in protecting the physical and mental health. It also helps to overcome the effects of stress experienced in life (Martowska, 2012).

Research Nowicki et al. (2016) demonstrated that reduced sleep quality is very widespread phenomenon in the adult population of Poles and the most frequently mentioned is the difficulty in falling asleep. Sleep disorders affect women more often than men. They are also an integral part of various forms of depressive disorders (Heitzman, 2009). Epidemiological studies conducted among American soldiers (Strelau, 2009) have shown that PTSD and depression were more frequent among those taking part in the mission in Iraq (19\%) and Afghanistan (11.3\%). Studies Ulmer et al. (2015) involving 1,238 participants; veterans and active duty military soldiers show a higher prevalence of various symptoms of sleep disorders among war veterans, compared with the general population. Epidemiological data from employees of military service on these disorders presented by the Mysliwiec et al. (2013) demonstrate the occurrence of mild obstructive sleep apnea (called. Obstructive sleep apnea - OSA) in 27.2\% surveyed, moderate or severe in $24.0 \%$ and insomnia in $24.7 \%$ of the surveyed soldiers.

Results of studies Rusch et al. (2015) emphasize the importance of raising the quality of sleep in reducing symptoms of depression, trauma and cognitive performance among military personnel. Group of soldiers diagnosed with insomnia was defined as a group of high risk for the development of disturbances coexisting: depression, posttraumatic stress disorder, and other due to sleep disorders. The aim of this study was to examine whether improving sleep quality soldiers will be associated with the weakening of the symptoms of post-traumatic stress, depression, and improve the quality of life of patients. Also checked whether are there changes in the concentration of neurotrophic factor brain derived neurotrophic factor - BDNF and insulin-like growth factor-1 - IGF-1. The initial stage involved in conducting clinical trial and laboratory analysis of the blood. Then, cognitive-behavioral disorders was conducted. The results showed a significant decrease in symptoms of depression and post traumatic experience and a significant increase in IGF-1 which suggests that the action applied effectively improve the quality of sleep and are an effective method of reducing the symptoms of depression and post-traumatic stress disorder. The positive results of cognitive-behavioral therapy in reducing sleep disturbance also highlights the publication Bramoweth and Germain (2013).

The soldiers participating in military activities are exposed to many negative consequences as a result of sustained combat stress, which in turn can decrease in quality of life by the occurrence of problems disrupting daily functioning. Over the last years, the expression of perceiving the needs of psychological support was developed and implemented documents regulating procedure, scope and forms of psychological help. There are among others The Act of 19 August 2011 by veterans of activities outside the country, Regulation of the Minister of National Defence of 12 March 2012 on psychological assistance given to veteran soldier or veteran injured soldier and the closest family members, Decision No. 44 / MON of the Minister of National Defence of December 29, 2009 on the 
prevention of psychological in the Armed Forces of the Republic of Polish or protective program of psychological peacekeepers outside the country and their families, Secretary of State for. Social and Professionalism MON of 20 July 2010. Currently, each mission participate specially trained specialists, especially psychologists who have specific tasks, among other things, participate in the tasks contingent support commanders in resolving conflicts, organize meetings and serve to support the soldiers participating in traumatic events, conduct individual and group consultations.

The health status of all the soldiers experiencing combat stress requires periodic and thorough control because diagnosis of disorders is difficult and they can appear even after a long period of time after the event lived. Many people also suppresses her fear, anxiety and other problems fearing further service in the army and the future of employment (Dudek, 2003). This in turn may lead to look for other ways to deal with problems; use psychoactive substances or drug abuse (Korzeniewski, 2008). Therefore it is extremely important to use therapeutic actions.

\section{Conclusions}

The respondents did not show soldiers pathological symptoms of sleep disorders, however, the results show some symptoms of reduction sleep quality based on the selected factors. The mere fact of a mission not decide the intensification of sleep problems and their greatest intensification was observed in those soldiers who have decided on a mission only once and among non-commissioned officers. The high military rank and the fact that multiple participation in the military mission seemed to be associated with better quality of sleep (more continuity and satisfactory duration), which may indicate a greater psychological resistance and coping strategies in difficult situations among the more experienced military. In addition, noted the relationship between the decrease in the quality of sleep and the fact traumatic experiences during military mission. Soldiers who have experienced fire contact with an opponent and / or suffered physical injury or participated in the event in which a man was injured or killed on the battlefield often evaluated a total sleep time as too short.

\section{References}

Babbie, E. (2009). Podstawy badań społecznych. Warszawa: Wydawnictwo Naukowe PWN.

Basińska, B. (2004). Dom to baza - funkcjonowanie rodzin żołnierzy pełniących służbę w warunkach ekstremalnych. In: O. Truszczyński, L. Konopka, K. Sikora, A. Rakowski, L. Kosiorek (eds.), Służba żołnierzy i funkcjonariuszy służb państwowych wykonujących zadania w warunkach ekstremalnych, tom 8 (pp. 55-69). Warszawa: Departament Wychowania i Promocji Obronności MON, Polskie Towarzystwo Naukowe Kultury Fizycznej w Wojsku.

Basińska, M. (2007). Inteligencja emocjonalna a typy zachowań i przeżyć w pracy w grupie żołnierzy zawodowych. Polskie Forum Psychologiczne, 12 (1), 80-92.

Bilikiewicz, A., Pużyński, S., Rybakowski, J., Wciórka, J. (2002). Psychiatria kliniczna. Wrocław: Wydawnictwo Medyczne Urban Partner.

Bramoweth, A.D., Germain, A. (2013). Deployment-related insomnia in military personnel and veterans. Curr. Psychiatry Rep., 15 (10), 401. DOI: 10.1007/s11920-013-0401-4.

Chou, H.W., Tzeng, W.C., Chou, Y.C., Yeh, H.W., Chang, H.A., Kao, Y.C., Huang, S.Y., Yeh, C.B., Chiang,, W.S., Tzeng N.S. (2016). Stress, Sleep and Depressive Symptoms in Active Duty Military Personnel. Am J Med Sci., 352 (2), 146-153. DOI: 10.1016/j. amjms.2016.05.013.

Dudek, B. (2003). Zaburzenie po stresie traumatycznym. Gdańsk: GWP.

Fornal-Pawłowska, M., Wołyńczyk-Gmaj, D., Szelenberger, W. (2011). Walidacja Ateńskiej Skali Bezsenności. Psychiatr. Pol., 45, 211-221.

Freeman, T., Kimbrell, T. (2004). Relationship of alcohol craving to symptoms of posttraumatic stress disorder in combat veterans. The Journal of Nervous and Mental Disease, 192 (5), 389-390. 
Heitzman, J. (2009). Zaburzenia snu - przyczyna czy skutek depresji? Psychiatria Polska, XLIII (5), 499-511.

Korzeniewski, K. (2008). Zaburzenia psychiczne na współczesnym polu walki. Polski Merkuriusz Lekarski, XXIV, 144.

Martowska, K. (2012). Psychologiczne uwarunkowania kompetencji społecznych. Warszawa: Liberi Libri.

Mysliwiec, V., McGraw, L., Pierce, R., Smith, P., Trapp, B., Roth, B.J. (2013). Sleep disorders and associated medical comorbidities in active duty military personnel. Sleep., 36 (2), 167-174. DOI: 10.5665/sleep.2364.

Nowicki, Z., Grabowski, K., Cubała, W.J., Nowicka-Sauers, K., Zdrojewski, T., Rutkowski, M., Bandosz, P. (2016). Rozpowszechnienie subiektywnej bezsenności w populacji polskiej. Psychiatria Polska, 50 (1), 165-173.

Piórowski, K. (2008). Poczucie koherencji a style radzenia sobie ze stresem dowódców żołnierzy zawodowych. Polskie Forum Psychologiczne, 13 (1), 50-60.

Rasmus, P., Makowska, D., Stetkiewicz-Lewandowicz, A., Sobów, T., Machała, W. (2013). Poczucie koherencji a występowanie zaburzeń po stresie traumatycznym w grupie zawodowych żołnierzy uczestniczących w misji wojskowej poza granicami kraju doniesienie wstępne. Anestezjologia i Ratownictwo, 7, 27-36.

Rusch, H.L., Guardado, P., Baxter, T., Mysliwiec, V., Gill, J.M. (2015). Improved Sleep Quality is Associated with Reductions in Depression and PTSD Arousal Symptoms and Increases in IGF-1 Concentrations. J Clin Sleep Med., 11 (6), $615-623$. DOI: $10.5664 / j c s m .4770$.

Soldatos, C.R., Dikeos, D.G., Paparrigopuolos, T.J. (2000). Athens Insomnia Scale: validation of an instrument based on ICD-10 criteria. J Psychosom Res., 48 (6), 555-560.

Strelau, J., Zawadzki, B., Kaczmarek, M. (2009). Konsekwencje psychiczne traumy: uwarunkowania i terapia. Warszawa: Wydawnictwo Naukowe Scholar.

Tomaszewska, I. (2008). Turnusy leczniczo-profilaktyczne w systemie opieki psychologicznej nad uczestnikami misji poza granicami państwa. Polski Merkuriusz Lekarski, XXV, Suppl. 1 (29), 29-34.

Ulmer, C.S., Van Voorhees, E., Germain, A.E., Voils, C.I., Beckham, J.C. (2015). VA Mid-Atlantic Mental Illness Research Education and Clinical Center Registry Workgroup, A Comparison of Sleep Difficulties among Iraq/Afghanistan Theater Veterans with and without Mental Health Diagnoses. J Clin. Sleep Med., 11 (9), 995-1005. DOI: 10.5664/jcsm.5012.

Cite this anticle aS: Stępień-Słodkowska, M., Ustianowski, P., Starkowska, A., Kotarska, K. (2017). Evaluation of the Quality of Sleep of the Professional Soldiers Population. Central European Journal of Sport Sciences and Medicine, 18 (2), 57-66. DOI: 10.18276/ cej.2017.2-06. 